\title{
Biocatalytic anti-Prelog reduction of prochiral ketones with whole cells of Acetobacter pasteurianus GIM1.158
}

\author{
Peng-Xuan Du', Ping Wei ${ }^{1}$, Wen-Yong Lou ${ }^{1,2^{*}}$ and Min-Hua Zong ${ }^{2^{*}}$
}

\begin{abstract}
Background: Enantiomerically pure alcohols are important building blocks for production of chiral pharmaceuticals, flavors, agrochemicals and functional materials and appropriate whole-cell biocatalysts offer a highly enantioselective, minimally polluting route to these valuable compounds. At present, most of these biocatalysts follow Prelog's rule, and thus the (S)-alcohols are usually obtained when the smaller substituent of the ketone has the lower CIP priority. Only a few anti-Prelog $(R)$-specific whole cell biocatalysts have been reported. In this paper, the biocatalytic anti-Prelog reduction of 2-octanone to $(R)$-2-octanol was successfully conducted with high enantioselectivity using whole cells of Acetobacter pasteurianus GIM1.158.

Results: Compared with other microorganisms investigated, Acetobacter pasteurianus GIM1.158 was shown to be more effective for the reduction reaction, affording much higher yield, product enantiomeric excess (e.e.) and initial reaction rate. The optimal temperature, buffer $\mathrm{pH}$, co-substrate and its concentration, substrate concentration, cell concentration and shaking rate were $35^{\circ} \mathrm{C}, 5.0,500 \mathrm{mmol} / \mathrm{L}$ isopropanol, $40 \mathrm{mmol} / \mathrm{L}, 25 \mathrm{mg} / \mathrm{mL}$ and $120 \mathrm{r} / \mathrm{min}$, respectively. Under the optimized conditions, the maximum yield and the product e.e. were $89.5 \%$ and $>99.9 \%$, respectively, in 70 minutes. Compared with the best available data in aqueous system (yield of 55\%), the yield of (R)-2-octanol was greatly increased. Additionally, the efficient whole-cell biocatalytic process was feasible on a 200-mL preparative scale and the chemical yield increased to $95.0 \%$ with the product e.e. being $>99.9 \%$. Moreover, Acetobacter pasteurianus GIM1.158 cells were proved to be capable of catalyzing the anti-Prelog bioreduction of other prochiral carbonyl compounds with high efficiency.

Conclusions: Via an effective increase in the maximum yield and the product e.e. with Acetobacter pasteurianus GIM1.158 cells, these results open the way to use of whole cells of this microorganism for challenging enantioselective reduction reactions on laboratory and commercial scales.
\end{abstract}

Keywords: Acetobacter pasteurianus GIM1.158, Anti-Prelog, Asymmetric reduction, 2-octanone, (R)-2-octanol

\section{Background}

Enantiomerically pure chemicals are important building blocks for production of chiral pharmaceuticals, flavors, agrochemicals and functional materials [1]. For instance, (R)-2-octanol is a versatile intermediate for the synthesis of FLCD (ferroelectric liquid crystals FLCs) and several optically active pharmaceuticals such as steroid and

\footnotetext{
* Correspondence: wylou@scut.edu.cn; btmhzong@scut.edu.cn ${ }^{1}$ Laboratory of Applied Biocatalysis, South China University of Technology, Guangzhou 510640, China

${ }^{2}$ State Key Laboratory of Pulp and Paper Engineering, College of Light Industry and Food Sciences, South China University of Technology, Guangzhou 510640, China
}

insecticidal ectohormone. Asymmetric reduction of prochiral carbobyl compounds is an efficient method to produce chiral alcohols [2-5]. Whole-cell based biocatalytic reduction has attracted great attention and has been extensively investigated in recent years for the unique advantages such as outstanding enantioselectivity, mild reaction conditions, environmental friendliness and regeneration of cofactors in situ [6-8]. So far, yeasts, bacteria, fungi, and even plant tissues have been extensively researched as biocatalysts for bio-reduction processes $[9,10]$, and many excellent biocatalytic reaction processes have been developed. However, most of these biocatalysts 
follow Prelog's rule [11], and thus the (S)-alcohols are usually obtained when the smaller substituent of the ketone has the lower CIP priority. Only a few anti-Prelog $(R)$ specific whole cell biocatalysts have been reported [12-17]. As far as we know, most of the previously reported anti-Prelog microorganisms have not been used for industrial preparation of chiral alcohols for their relatively low catalytic activity and stereoselectivity. Take the substrate 2-octanone as example, the best reported result was given by a recombinant Escherichia coli overexpressing the genes of a Lactobacillus brevis alcohol dehydrogenase (LB-ADH) and a Candida boidinii formate dehydrogenase (CB-FDH) for cofactor regeneration [17]. In buffer system, the recombinant $E$. coli gave a very low yield of just $2 \%$ on a $1.4 \mathrm{~mL}$ scale, which increased to $55 \%$ when the bioreduction was on a $200 \mathrm{~mL}$ scale. Using ionic liquids (ILs) or organic solvents as a second phase could significantly increase the product yield [14,17-20]. For industrial application, the discovery of more efficient microorganisms would be of great significance.

On the other hand, Acetobacter is a kind of bacteria that is widely used for production of acetic acid owing to its large bioavailibility, easiness of treatment, less environmental pollution, low cost, and mild cultivation conditions [21]. Recently, Acetobacter sp. has been found to produce carbonyl reductase and shown catalytic activity for reduction of carbonyl compounds [22]. However, to our best knowledge, the use of Acetobacter sp. as a biocatalyst for the asymmetric reduction of prochiral ketones remains unexplored, with only few accounts published by us $[16,20,23,24]$. In these cases, a new acetic acid bacterium, Acetobacter sp. CCTCC M209061, was isolated from China kefir grains, and was capable of effectively catalyzing anti-Prelog asymmetric reduction of a number of carbonyl compounds with excellent enantioselectivity. Therefore, it can be well recognized that Acetobacter has the tremendous potential for asymmetric synthesis of valuable enantiopure alcohols.

In the present study, a number of microorganisms including acetic acid bacteria were tested for their potential for biocatalytic anti-Prelog asymmetric reduction of 2-octanone to $(R)$-2-octanol. Another Acetobacter pasteurianus GIM1.158 was found to be more active and enantioselective in catalyzing the bioreduction of 2octanone and, for the first time, was applied as the biocatalyst for the asymmetric reduction of prochiral ketones. The effects of several crucial variables on the bioreduction of 2-octanone with whole cells of Acetobacter pasteurianus GIM1.158 were explored systematically. Also, the efficient biocatalytic process was evaluated on a preparative scale, and the applicability of the promising Acetobacter pasteurianus GIM1.158 was examined for the bioreduction of other prochiral ketones.

\section{Results and discussion}

Comparison of the biocatalytic enantioselective reduction of 2-octanone with Acetobacter pasteurianus GIM1.158 and other potential microorganisms

A variety of microorganisms have been reported to be efficient in catalyzing prochrial ketones to enantiomerically pure chrial alcohols [16,25-29]. Therefore, several commercial available microorganisms (Acetobacter pasteurianus GIM1.158, Acetobacter sp. CCTCC M209061, Bacillus cereus AS1.126, Pseudomonas putica GIM1.193, Candida parapsilosis CCTCCM203011, Candia tropicalis CICC1316, Saccharomyces cerevisiae GIM 2.34, Rhodotorula sp. AS2.2241, Pseudomonas oleovorans GIM1.304)were comparatively tested for their potential for the preparation of (R)-2-octanol via asymmetric reduction of 2-octanone in TEA- $\mathrm{HCl}$ buffer $(50 \mathrm{mmol} / \mathrm{L}, \mathrm{pH} 5.0)$. From the data summarized in Table 1, all of the nine tested strains, including five kinds of bacteria and four kinds of yeast cells, exhibited catalytic activity. Although these four yeasts were able to catalyze the asymmetric reduction of 2octanone, they gave the undesired (S)-2-octanol. The varied stereoselectivity of these strains might be attributable to the expression of different reductases in the cells, which needs further investigation. Two Acetobacter strains, Acetobacter pasteurianus GIM1.158 and Acetobacter sp. CCTCC M209061 were capable of catalyzing the antiPrelog stereoselective reduction of 2-octanone to $(R)-2$ octanol, and showed more activity and enantioselectivity compared to other microorganisms examined. Acetobacter pasteurianus GIM1.158 was slightly superior to Acetobacter sp. CCTCC M209061 in terms of the initial reaction rate, yield and product e.e. for the bioreduction of 2octanone under the same reaction conditions. Besides, it was more easy and cheap to cultivate Acetobacter pasteurianus GIM1.158 cells. Obviously, Acetobacter pasteurianus GIM1.158 cell exhibited greater potential for efficient asymmetric reduction of 2-octanone to enantiopure $(R)$-2-octanol.

\section{Effects of several key variables on the biocatalytic reduction of 2-octanone to (R)-2-octanol with Acetobacter pasteurianus GIM1.158 cells}

To gain a deeper insight into the bioreduction and improve the results with respect to the initial reaction rate, the yield and the product e.e., a systematic investigation was made of the effects of several important variables such as reaction temperature, buffer $\mathrm{pH}$, different co-substrates and their concentration, substrate concentration, cell concentration and shaking rate on the reaction.

In general, temperature can affect the activity, the selectivity and the stability of a biocatalyst and the equilibrium of a reaction as well. Hence, the bioreduction was conducted at different reaction temperatures to see its impact on the reaction. As can be seen in Figure 1, 
Table 1 Biocatalytic asymmetric reduction of 2-octanone with various strains

\begin{tabular}{|c|c|c|c|c|c|c|}
\hline Entry & Strain & $\mathrm{V}_{0}\left(\times 10^{-1} \mu \mathrm{mol} / \mathrm{min}\right)$ & Time (h) & $\mathrm{Y}^{a}(\%)$ & e.e. (\%) & Config. \\
\hline 1 & Acetobacter pasteurianus GIM1.158 & 1.07 & 2.0 & 53.4 & 98.5 & $R$ \\
\hline 2 & Acetobacter sp. CCTCC M209061 & 0.79 & 2.0 & 43.6 & 97.7 & $R$ \\
\hline 3 & Bacillus cereus AS1.126 & 0.12 & 4.0 & 11.6 & 56.1 & $s$ \\
\hline 4 & Pseudomonas putica GIM1.193 & 0.09 & 4.0 & 8.7 & 35.3 & $s$ \\
\hline 5 & Candida parapsilosis CCTCCM203011 & 0.84 & 4.0 & 64.2 & 66.3 & $s$ \\
\hline 6 & Candia tropicalis CICC1316 & 0.87 & 2.0 & 91.5 & 10.5 & $s$ \\
\hline 7 & Saccharomyces cerevisiae GIM 2.34 & 0.45 & 2.0 & 45.4 & $>99.9$ & $s$ \\
\hline 8 & Rhodotorula sp. AS2.2241 & 0.55 & 2.0 & 54.7 & 22.3 & $S$ \\
\hline 9 & Pseudomonas oleovorans GIM1.304 & 0.60 & 2.0 & 60.3 & 18.1 & s \\
\hline
\end{tabular}

Reaction conditions: $2 \mathrm{mLTEA}-\mathrm{HCl}(50 \mathrm{mmol} / \mathrm{L}, \mathrm{pH} 5.0), 25 \mathrm{mg} / \mathrm{mL}$ wet free cells, $10 \mathrm{mmol} / \mathrm{L}$ 2-octanone, $100 \mathrm{mmol} / \mathrm{L}$ isopropaanol, $30^{\circ} \mathrm{C}, 180 \mathrm{r} / \mathrm{min}$. $\mathrm{Y}^{\mathrm{a}}$ : The maximum yield.

within the examined temperature range between 20 and $50^{\circ} \mathrm{C}$, both the initial reaction rate and the yield were affected markedly, while the product e.e. showed no significant variation and kept above $98.5 \%$. The reaction accelerated substantially and the product yield increased with increasing temperature from 20 to $35^{\circ} \mathrm{C}$. When the temperature was above $35^{\circ} \mathrm{C}$, further increase in reaction temperature led to a clear drop in the initial reaction rate and the yield, which could be attributed to the partial inactivation of the biocatalysts at a higher temperature. Taking into account the initial reaction rate and yield, $35^{\circ} \mathrm{C}$ was considered as the optimum temperature for the bioreaction.

It is well known that $\mathrm{pH}$ play a crucial role in biocatalytic reactions. Variation of $\mathrm{pH}$ values could not only influence the activity and the selectivity of the biocatalyst, but also the regeneration of the coenzyme present in the microbial cells, which in turn affects the bioreduction rate markedly $[30,31]$. To our knowledge, buffer

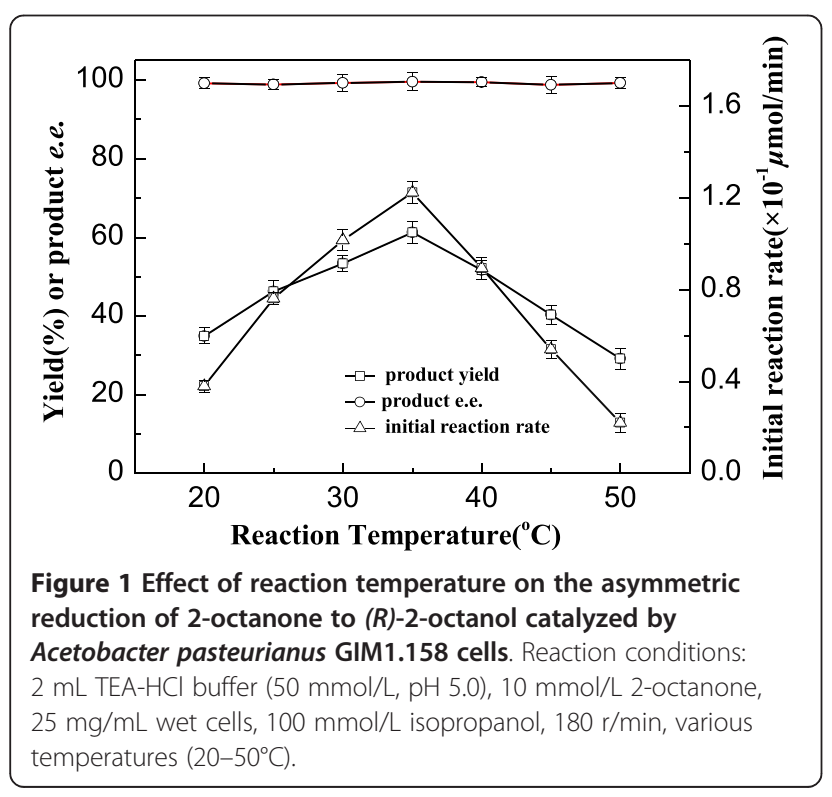

$\mathrm{pH}$ can alter the ionic state of the enzymes involved in the reaction and affect the local polarity of enzymes' active sites. As a result, an optimum $\mathrm{pH}$ value should exist for the bioreduction. As illustrated in Figure 2, buffer $\mathrm{pH}$ exerted a significant impact on both the initial reaction rate and the maximum yield of the reaction. Both of the reaction rate and the product yield increased with the rise of $\mathrm{pH}$ from 3.0 to 5.0. Further increasing buffer $\mathrm{pH}$, however, resulted in a significant drop in product yield and initial reaction rate. Within the assayed buffer $\mathrm{pH}$ range from 3.0 to 7.0 , there was only marginal change in the product e.e.. Obviously, the optimum buffer $\mathrm{pH}$ for the biocatalytic reaction was 5.0.

Coenzyme recycling plays a special role in biocatalytic reduction reactions. The reductions could proceed smoothly with whole cells without adding expensive coenzyme (NADH or NADPH) only if a co-substrate is present for recycling the coenzyme [32]. Different co-substrates had been employed for the regeneration of coenzyme in some bioreduction reactions and varied largely in terms of

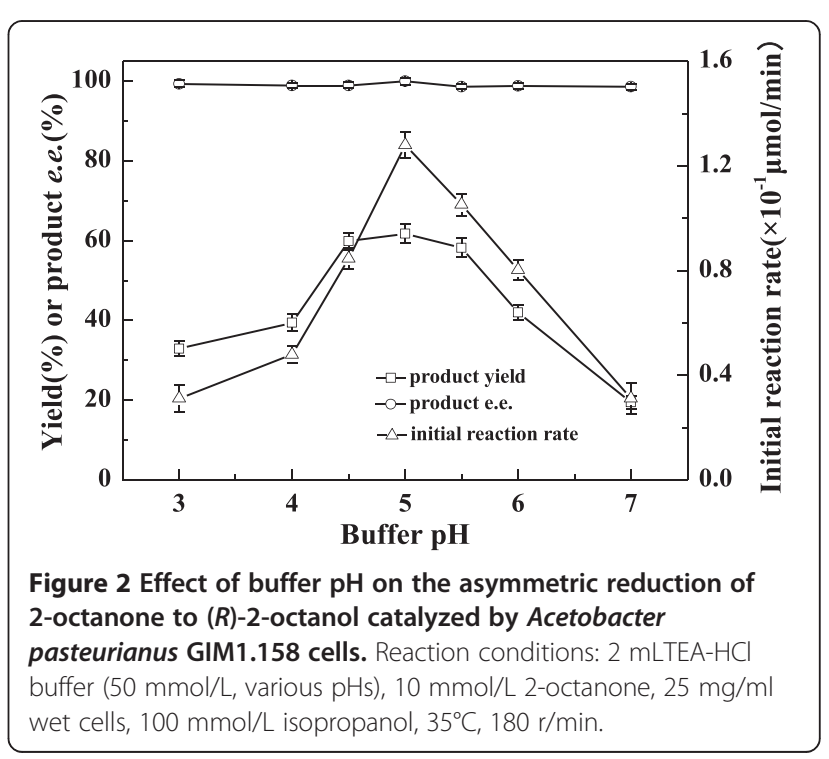


the product yield and e.e. $[27,33]$. In this study, several commonly used co-substrates (glucose, glycerol, ethanol, isopropanol, methanol, fructose, sodium lactate) were tested to find the best one for the bioreduction of 2octanone to $(R)$-2-octanol with Acetobacter pasteurianus GIM1.158 cells. As shown in Table 2, 2-octanone could be reduced to 2-octanol without adding any co-substrate (control), but the initial reaction rate and the maximum yield was very low (only $0.4 \times 10^{-2} \mu \mathrm{mol} / \mathrm{min}$ and $2 \%$, respectively). Adding any single co-substrate markedly influenced the bioreaction. Among these 7 different cosubstrates, ethanol gave the fastest reaction rate and the highest product yield while the product e.e. was relatively low (only 80.6\%). It was obvious that glucose, sodium lactate and isopropanol could also be effectively utilized to regenerate coenzymes. The problem with the former two co-substrates was the low product e.e. (75.8\% and $72.3 \%$, respectively). Taken together, isopropanol gave the best result, with relatively high product yield (60.5\%) and e.e. (above 99.9\%). It is interesting to further investigate why the different co-substrates gave such an impact on the stereoselectivity of Acetobacter pasteurianus GIM1.158 cells. Additionally, increasing isopropanol concentration from 50 to $500 \mathrm{mmol} / \mathrm{L}$ gave rise to an increase in the initial reaction rate from $0.8 \times$ $10^{-1} \mu \mathrm{mol} / \mathrm{min}$ to $3.2 \times 10^{-1} \mu \mathrm{mol} / \mathrm{min}$ and the $\max -$ imum yield from $52.5 \%$ to $89.1 \%$ (shown in Figure 3 ). The product e.e. kept constantly above $98.5 \%$ within the tested range of isopropanol concentration. It has been proved that Acetobacter pasteurianus GIM1.158 could tolerate high concentration of isopropanol up to $4 \mathrm{~mol} / \mathrm{L}$.

As can be seen in Figure 4, the reaction accelerated and the maximum product yield showed no significant decrease when substrate concentration increased from 5 to $40 \mathrm{mmol} / \mathrm{L}$, which was the maximum concentration of 2-octanone in buffer with the help of large amount solubilizer DMSO, suggesting no substrate inhibition in the tested range of substrate concentration. Throughout

\begin{tabular}{|c|c|c|c|c|}
\hline Co-substrate & $\mathrm{V}_{0}\left(\times 10^{-2} \mu \mathrm{mol} / \mathrm{min}\right)$ & Time (h) & Yield (\%) & e.e. (\%) \\
\hline No cosubstrate & 0.4 & 6.0 & 2.0 & 70.2 \\
\hline Glucose & 4.4 & 6.0 & 41.9 & 75.8 \\
\hline Glycerol & 1.8 & 6.0 & 18.7 & 8.6 \\
\hline Ethanol & 15.5 & 2.0 & 82.4 & 80.6 \\
\hline Isopropanol & 12.2 & 2.0 & 60.5 & $>99.9$ \\
\hline Methanol & n.r. & 6.0 & n.r. & n.r. \\
\hline Fructose & n.r. & 6.0 & n.r. & n.r. \\
\hline Sodium lactate & 13.8 & 2.0 & 72.4 & 72.3 \\
\hline
\end{tabular}

Reaction conditions: $2 \mathrm{~mL}$ TEA-HCl buffer $(50 \mathrm{mmol} / \mathrm{L}, \mathrm{pH} 5.0), 25 \mathrm{mg} / \mathrm{mL}$ wet cells, $10 \mathrm{mmol} / \mathrm{L}$ 2-octanone, $100 \mathrm{mmol} / \mathrm{L}$ co-substrates, $35^{\circ} \mathrm{C}, 180 \mathrm{r} / \mathrm{min}$.

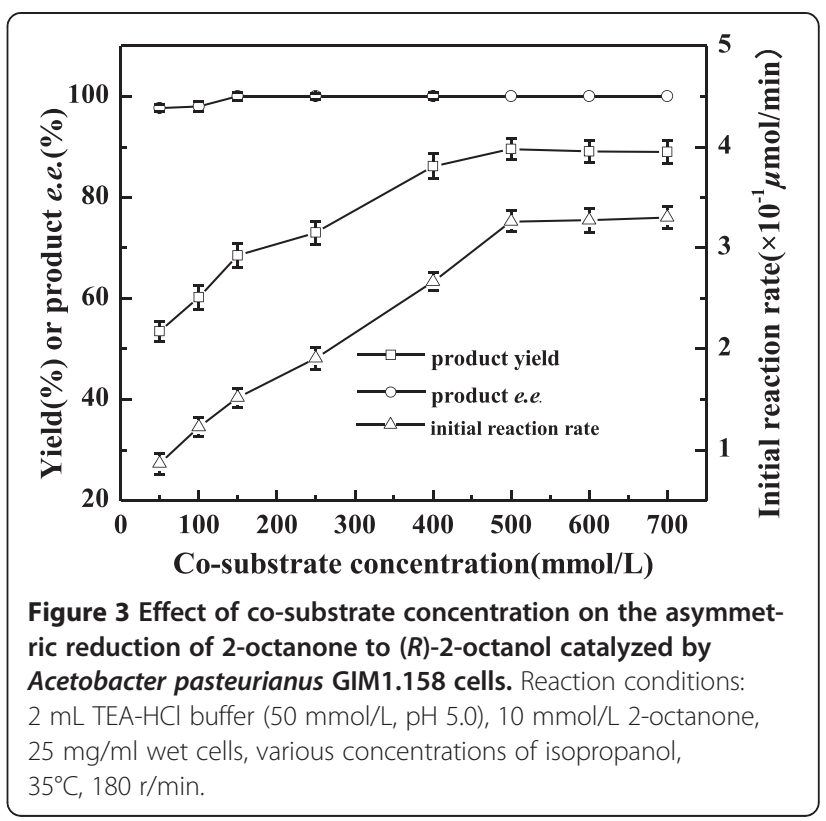

the range of substrate concentrations tested, the product e.e. showed no clear variation and remained above $98.5 \%$. Obviously, the optimum concentration of 2-octanone was $40 \mathrm{mmol} / \mathrm{L}$ for the bioreduction with whole cell of Acetobacter pasteurianus GIM1.158 conducted in aqueous reaction system. It was noticed that Acetobacter pasteurianus GIM1.158 could tolerate fairly high concentrations of 2-octanone and 2-octanol. For the microbial reduction of 2-octanone, other microorganisms reported could generally tolerate relatively lower concentration of 2-octanone $[34,35]$. In the case of Baker's yeast used as biocatalyst for the bioreduction of 2octanone [34], the yield of $(S)$-2-octanol decreased

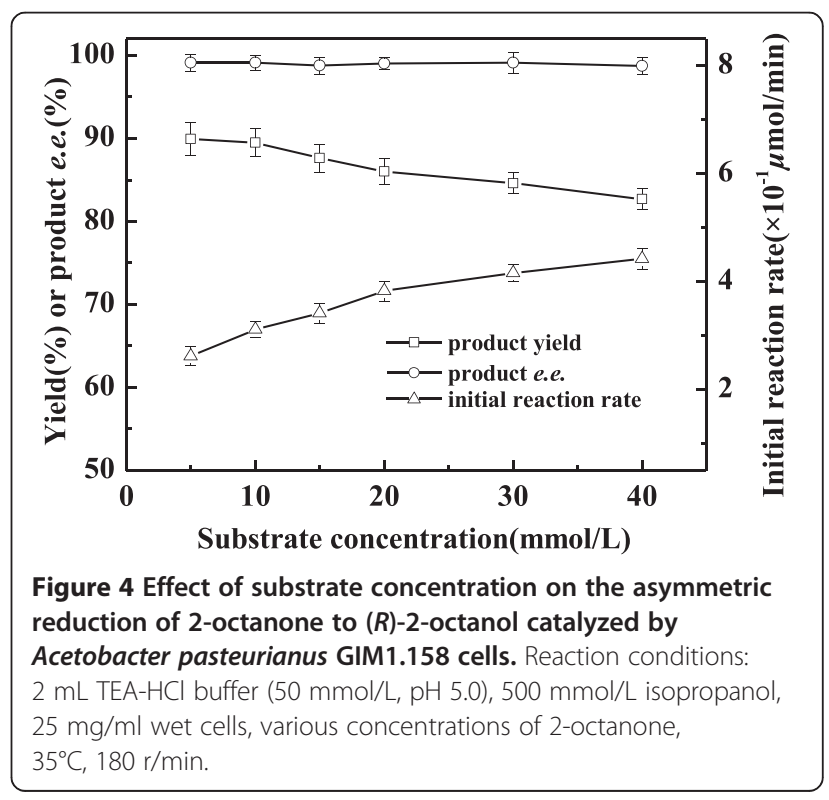


rapidly from $81 \%$ to $60 \%$ with increasing 2 -octanone concentration from 2 to $10 \mathrm{mmol} / \mathrm{L}$. For Geotrchum candidum IFO 4597, the most suitable concentration of 2 -octanone was around $20 \mathrm{mmol} / \mathrm{L}$ and the obtained yield of (S)-2-octanol was about 62\% [35]. Thus, Acetobacter pasteurianus GIM1.158 exhibited more promising and competitive for the biocatalytic asymmetric reduction of 2-octanone to $(R)$-2-octanol.

Cell concentration has not always been taken into account as a key factor for the whole cell-based biocatalytic processes. But we think it is an important factor to be considered in order to save biocatalyst as much as possible, making the bioreduction process more economically competitive. As shown in Figure 5, the initial reaction rate increased from 2.6 to $4.4 \times 10^{-1} \mu \mathrm{mol} / \mathrm{min}$ with increasing cell concentration from 10 to $25 \mathrm{mg} / \mathrm{mL}$, while the maximum product yield from $70.6 \%$ to $82.9 \%$. The product e.e. remained constant (above 98.5\%) in the range of cell concentration. From an economic point of view, $25 \mathrm{mg} / \mathrm{L}$ Acetobacter pasteurianus GIM1.158 cells was enough for the bioreduction of 2-octanone to $(R)$-2-octanol.

In general, shaking rate affects the diffusion of substrate and product in the reaction system, which would further affect the initial reaction rate and product yield. It was found that the reaction accelerated rapidly with increasing shaking rate from 60 to $120 \mathrm{r} / \mathrm{min}$ (Figure 6), with an obvious enhancement in the initial reaction rate from 3.6 to $5.2 \times 10^{-1} \mu \mathrm{mol} / \mathrm{min}$, indicating that the mass transfer was the reaction rate limiting step. The optimum shaking rate was shown to be $120 \mathrm{r} / \mathrm{min}$, above which little decrease in the initial reaction rate and the maximum yield was observed. Within the range of shaking

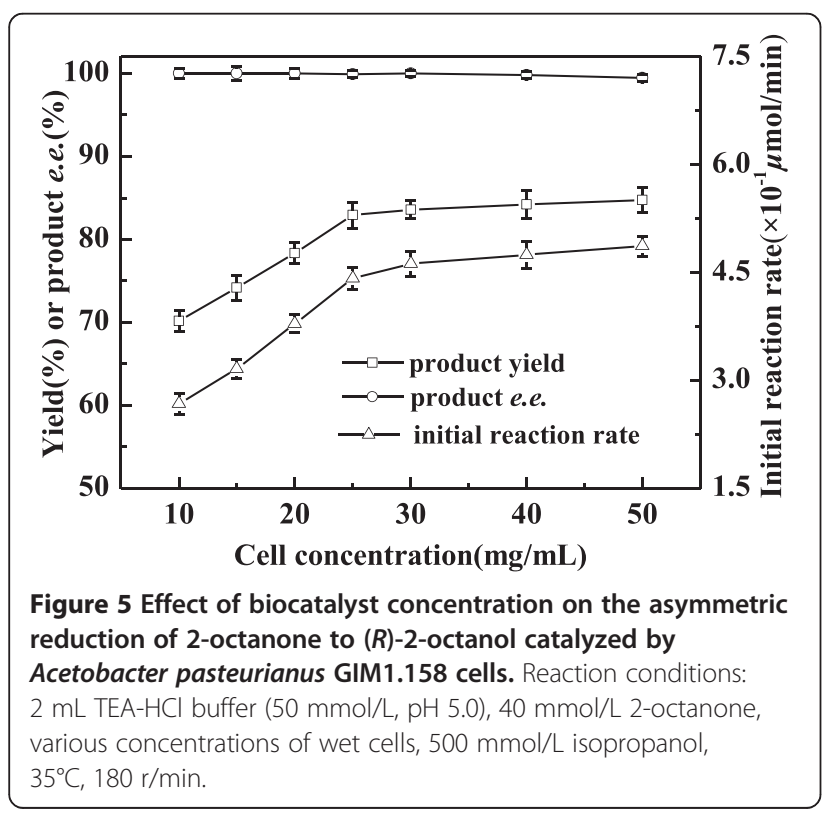

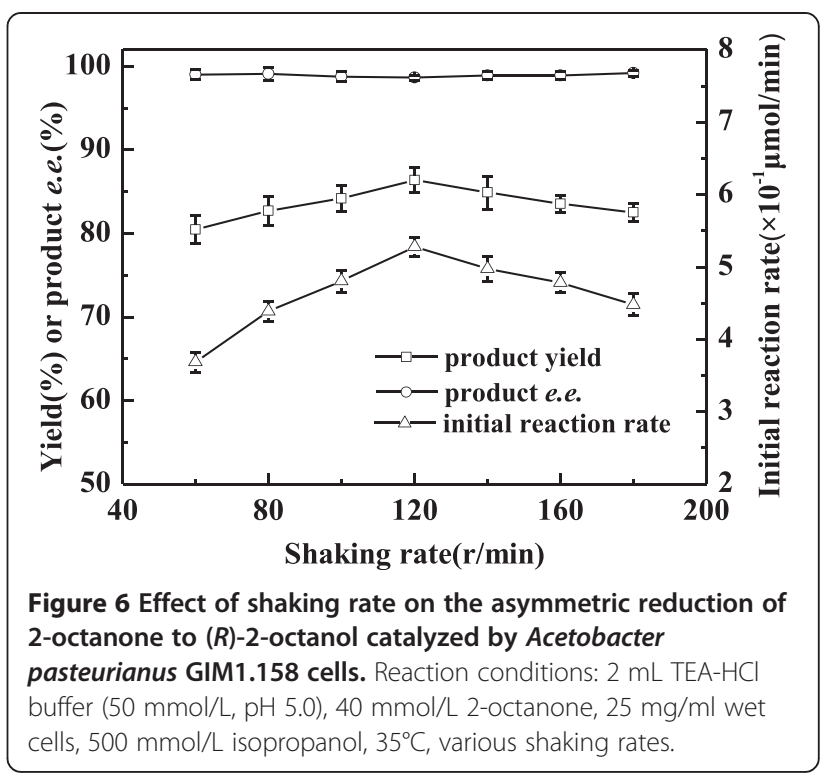

rate tested, the product e.e. showed no significant alteration and remained above $98.5 \%$.

Under the optimized reaction conditions described above (the optimal reaction temperature, buffer $\mathrm{pH}$, cosubstrate concentration, substrate concentration, cell concentration and shaking rate were $35^{\circ} \mathrm{C}, 5.0,500 \mathrm{mmol} / \mathrm{L}$ isopropanol, $40 \mathrm{mmol} / \mathrm{L}, 25 \mathrm{mg} / \mathrm{mL}$ and $120 \mathrm{r} / \mathrm{min}$, respectively), the biocatalytic asymmetric reduction of 2-octanone to $(R)$-2-octanol with Acetobacter pasteurianus GIM1.158 cells gave an encouraging result, with a yield of $89.5 \%$ and a product e.e. above $99.9 \%$ at a reaction time of $70 \mathrm{~min}$.

\section{Biocatalytic anti-Prelog stereoselective reduction of various prochiral carbonyl compounds}

In order to rationally evaluate the potential of Acetobacter pasteurianus GIM1.158 cells for the biocatalytic asymmetric reduction of carbonyl compounds, other nine prochrial carbonyl compounds (2-Pentanone, Pinacolone, 4'-Chloroacetophenone, 4'-Methyl-acetophenone, 4'-Hydroxyacetophenone, 3-Chloropropiophenone, Ethyl 4-chloroacetoacetate, Ethyl acetoacetate and Methyl acetoacetate) were also tested for the bioreduction conducted in TEA-HCl buffer. As listed in Table 3, Acetobacter pasteurianus GIM1.158 was able to catalyze the anti-Prelog asymmetric reductions of all the tested ketones to the corresponding alcohols with high enantioselectivity, and the achieved product e.e. reached more than $92.0 \%$. When the substrates were aliphatic ketones, the yield and the product e.e. increased with the side-chain of the carbonyl group. In the case of prochiral keto esters, the microbial cells exhibited high catalytic activity and enantioselectivity. For example, the obtained yield of ethyl $(R)$-3-hydroxybutyrate with Acetobacter pasteurianus 
Table 3 Biocatalytic anti-Prelog stereoselective reduction of various prochiral carbobyl compounds with Acetobacter pasteurianus GIM1.158 cells

\begin{tabular}{|c|c|c|c|c|c|}
\hline Prochiral ketones & Structure & $\mathrm{V}_{0}\left(\times 10^{-1} \mu \mathrm{mol} / \mathrm{min}\right)$ & Yield (\%) & e.e.. (\%) & Config. \\
\hline 2-Pentanone & & 9.78 & 81.5 & 92.0 & $R$ \\
\hline Pinacolone & & 11.3 & 94.5 & 95.2 & $R$ \\
\hline 4'-Chloroacetophenone & & 7.3 & 60.4 & $>99.9$ & $R$ \\
\hline 4'-Methyl-acetophenone & & 11.9 & 99.5 & 99.6 & $R$ \\
\hline 4'-Hydroxyacetophenone & & 11.7 & 97.8 & 97.1 & $R$ \\
\hline 3-Chloropropiophenone & & 5.7 & 94.9 & 99.7 & $S$ \\
\hline Ethyl 4-chloroacetoacetate & & 14.9 & 74.4 & 97.3 & $s$ \\
\hline Ethyl acetoacetate & & 17.2 & 85.8 & 98.7 & $R$ \\
\hline Methyl acetoacetate & & 18.6 & 92.9 & 97.2 & $R$ \\
\hline
\end{tabular}

Reaction conditions: $2 \mathrm{~mL} \mathrm{TEA-HCl} \mathrm{buffer}(50 \mathrm{mmol} / \mathrm{L}, \mathrm{pH} 5.0), 25 \mathrm{mg} / \mathrm{mL}$ wet cells, $5 \mathrm{mmol} / \mathrm{L}$ various prochiral ketones, $500 \mathrm{mmol} / \mathrm{L}$ isopropanol, $35^{\circ} \mathrm{C}, 120 \mathrm{r} / \mathrm{min}$, reaction time $2 \mathrm{~h}$.

GIM1.158 was slightly higher than that with Acetobacter sp. CCTCC M209061 in aqueous reaction system (85.8\% vs 82.6\%) [36]. Besides, Acetobacter pasteurianus GIM1.158 was more active and effective in enantioselectively catalyzing the bioreduction of methyl acetoacetate to methyl $(R)$-3-hydroxybutyrate, which was not reported previously. When the tested substrates were aromatic ketones, apart from 4'-chloroacetophenone, the achieved yield (more than 94.9\%) and the product e.e. (more than 97.1\%) were very satisfactory. In particular, the biocatalytic asymmetric reduction of 3-chloropropiophenon to (S)-3-chloro-1-phenylpropanol was successfully conducted using Acetobacter pasteurianus GIM1.158 cells with high product yield (94.9\%) and product e.e. (99.7\%), which were superior to those with Candida utilis reported previously (yield: $85 \%$; product e.e.: 99.5\%) [37]. The above-described results clearly showed that the established biocatalytic system with
Acetobacter pasteurianus GIM1.158 cells can also be successfully used for efficient synthesis of other important chiral alcohols.

\section{Preparative scale bioreduction of 2-octanone to (R)-2-octanol}

Biotransformation on a 200-mL scale was performed to determine scalability of biocatalytic asymmetric reduction of 2-octanone to (R)-2-octanol with Acetobacter pasteurianus GIM1.158 cells. The reaction process was monitored by GC analysis and the product was extracted from the reaction mixture with acetic ether when no more substrate was converted to the product. A final chemical yield of 95.0\% was achieved and the product e.e. was above $99.9 \%$ in $70 \mathrm{~min}$. To our best knowledge, the reported maximum yield of biotransformation of 2-octanone to $(R)$-2-octanol in buffer was only $55 \%$ while the highest substrate concentration was much lower [17]. 
It should be emphasized that the bioreduction process described above suffered from the drawback of low substrate concentration and overall productivity for the large-scale industrial application because of the low solubility of 2-cotanone in buffer system. We believe that the reaction efficiency could be further improved by employing a biphasic system containing an organic solvent or preferably a biocompatible ionic liquid to relieve the restriction of low solubility of substrate in buffer as the concentration of 2-octanone in the second phase could reach up to $1.5 \mathrm{~mol} / \mathrm{L}$.

\section{Conclusions}

The preparation of enantiopure $(R)$-2-octanol on a $200-\mathrm{mL}$ preparative scale can be successfully conducted through anti-Prelog asymmetric bioreduction of 2-octanone with Acetobacter pasteurianus GIM1.158 cells. Under the optimal conditions $\left(35^{\circ} \mathrm{C}, \mathrm{pH} 5.5,500 \mathrm{mmol} / \mathrm{L}\right.$ isopropanol as co-substrate, substrate concentration $40 \mathrm{mmol} / \mathrm{L}$, cell concentration $25 \mathrm{mg} / \mathrm{L}$, shaking rate $120 \mathrm{r} / \mathrm{min}$ ), the $\max -$ imum yield and the product e.e. were $95.0 \%$ and above 99.9\% respectively in $70 \mathrm{~min}$. Furthermore, Acetobacter pasteurianus cells exhibited high catalytic activity for highly enantioselective reduction of various kinds of carbonyl compounds.

\section{Material and methods}

Biological and chemical materials

Acetobacter pasteurianus GIM1.158 was purchased from Guangdong Culture Collection Center. Other strains (Acetobacter sp. CCTCC M209061, Bacillus cereus AS1.126, Pseudomonas putica GIM1.193, Candida parapsilosis CCTCCM203011, Candia tropicalis CICC1316, Saccharomyces cerevisiae GIM 2.34, Rhodotorula sp. AS2.2241, Pseudomonas oleovorans GIM1.304) used in this work were kept in our laboratory (Lab of Applied Biocatalysis, South China University of Technology, China).

2-Octanone (99\% purity) and ethyl acetoacetate were purchased from Alfa Aesar (USA). (R)-2-Octanol (98\% purity) and (S)-2-octanol (98\% purity) were from SigmaAldrich (USA). Other prochiral ketones and the corresponding alcohols were obtained from Aldrich-Fluka and were all over $97 \%$ purity. All other chemicals were from commercial sources and were of analytical grade.

\section{Cell cultivation}

Acetobacter pasteurianus GIM1.158 cells were cultivated on medium containing $6 \mathrm{~g} / \mathrm{L}$ yeast extract, $6 \mathrm{~g} / \mathrm{L}$ peptone, $10 \mathrm{~g} / \mathrm{L}$ sodium lactate solution, $0.75 \mathrm{~g} / \mathrm{L} \mathrm{K}_{2} \mathrm{HPO}_{4}$, $0.5 \mathrm{~g} / \mathrm{L} \mathrm{NaH} \mathrm{NO}_{4}, 0.1 \mathrm{~g} / \mathrm{L} \quad \mathrm{MnSO}_{4}, 0.2 \mathrm{~g} / \mathrm{L} \mathrm{MgSO}_{4}$, $0.1 \mathrm{~g} / \mathrm{L} \mathrm{CaCl} \mathrm{Cl}_{2}$. Other bacteria cells were grown in Nutrient Broth Medium (NB). Yeast cells were cultivated in Yeast Extract Peptone Dextrose Medium (YPD).

\section{General procedure for biocatalytic asymmetric reductions of prochiral ketones}

In a typical experiment, $2.0 \mathrm{~mL}$ of TEA-HCL buffer (pHs 3.0-7.0, $50 \mathrm{mmol} / \mathrm{L})$ containing wet cells $(10-50 \mathrm{mg} / \mathrm{mL})$ and a predetermined quantity of co-substrate (50$700 \mathrm{mmol} / \mathrm{L})$ were added to a10-mL Erlenmeyer flask capped with a septum, and pre-incubated in a waterbath shaker at a specified shaking rate $(60-180 \mathrm{r} / \mathrm{min})$ and an appropriate temperature $\left(20-50^{\circ} \mathrm{C}\right)$ for $15 \mathrm{~min}$. The reaction was initiated by adding various prochial ketones $(5-40 \mathrm{mmol} / \mathrm{L})$ to the mixture. Aliquots $(20 \mu \mathrm{L})$ were withdrawn at specified time intervals. The product and the residual substrate were extracted with ethyl acetate $(40 \mu \mathrm{L})$ for twice containing $5.0 \mathrm{mmol} / \mathrm{L} n$-decane (as internal standard) prior to GC analysis. Details about reaction temperature, buffer $\mathrm{pH}$, substrate concentration, cosubstrate concentration, cell concentration and shaking rate are specified for each case.

\section{Preparative scale biocatalytic reduction of 2-octanone to (R)-2-octanol}

The preparative scale biocatalytic reduction of 2-octanone with whole cells of Acetobacter pasteurianus GIM1.158 was performed under the optimized reaction conditions. The bioreduction reaction was conducted by adding $5 \mathrm{~g}$ wet cells of Acetobacter pasteurianus ( $25 \mathrm{mg} / \mathrm{mL}$ ) and $8 \mathrm{mmol}$ of 2 -octanone $(40 \mathrm{mmol} / \mathrm{L})$ to $200 \mathrm{~mL}$ of TEA$\mathrm{HCl}$ buffer $(50 \mathrm{mmol} / \mathrm{L}, \mathrm{pH} 5.0$ ) containing $500 \mathrm{mmol} / \mathrm{L}$ isopropanol as co-substrate at $35^{\circ} \mathrm{C}$ and $120 \mathrm{r} / \mathrm{min}$. The reaction was terminated when no substrate was transformed to product any more. Then the product and the residual substrate were extracted with ethyl acetate $(2 \times 200 \mathrm{~mL})$. The yield and e.e. of $(R)$-2-octanol were determined by GC analysis.

\section{GC analysis}

The reaction mixture was analyzed by a Shimadzu GC2010 with a flame ionization detector and a HP-chiral $\mathrm{CB}$ column $(30 \mathrm{~m} \times 25 \mathrm{~mm} \times 0.25 \mathrm{~m})$ (USA). The split ratio was 50:1. The injector and the detector were both at $250^{\circ} \mathrm{C}$. The carrier gas was nitrogen (>99.9). 2-Octanol was derived with trifluoroacetic anhydride before $\mathrm{GC}$ analysis. The column temperature was held at $110^{\circ} \mathrm{C}$ and the flow rate of nitrogen was $0.75 \mathrm{~mL} / \mathrm{min}$. The retention times for derived 2-octanol, $n$-decane and 2-octanone were 3.9, 4.1 and $4.7 \mathrm{~min}$. For the determination of the product e.e., the column temperature was kept at $85^{\circ} \mathrm{C}$ for 15 min while the flow rate of nitrogen in the column was $0.5 \mathrm{~mL} / \mathrm{min}$. The retention times for $(S)$-2-octanol and (R)-2-octanol were 12.28 and $12.51 \mathrm{~min}$, respectively. For other substrates and the corresponding products, the column temperature, the flow rate of nitrogen in the column and the retention times were as follows. 
2-Pentanone/2-pentanol, 3,3-dimethyl-2-butanone/ 3,3-dimethyl-2-butanol: $80^{\circ} \mathrm{C}, 13.5 \mathrm{~min}, 60^{\circ} \mathrm{C} / \mathrm{min}$ to $145^{\circ} \mathrm{C}$, retention times: derivatized $(S)$-2-pentanol (11.1 $\mathrm{min})$, derivatized $(R)$-2-pentanol (11.4 $\mathrm{min}), 2$ pentanone (16.2 min); derivatized (S)-2-(3,3-dimethyl)butanol (9.6 min), derivatized $(R)$-2-(3,3-dimethyl)butanol (9.9 $\mathrm{min}), 3,3$-dimethyl-2-butanone(15.7 $\mathrm{min}) .4$ '-Methoxyacetophenone/1-(4'-methoxyphenyl) ethanol, 4'-chloroacetophenone/1-(4'-chlorophenyl) ethanol, 4'-hydroxyace tophenone/1-(4'-hydroxyphenyl)ethanol: $140^{\circ} \mathrm{C}(10 \mathrm{~min})$, $1^{\circ} \mathrm{C} / \mathrm{min}$ to $145^{\circ} \mathrm{C}(4 \mathrm{~min})$, retention times: 4-metho xyacetophen-one (11.6 $\mathrm{min}),(R)-1-(4$-'methoxyphenyl) ethanol (15.2 $\mathrm{min}),(S)-1-(4 '-$ methoxyphenyl)ethanol (15.5 min); 4'-chloroacetophenone $(8.3 \mathrm{~min}),(R)-1-(4$ chlorophenyl)ethanol (12.2 $\mathrm{min}),(S)-1$-(4'-chlorophenyl) ethanol (12.6 min); 4'-hydroxyacetophenone(10.1 $\mathrm{min})$, (S)-1-(4'-hydroxyphenyl)ethanol (14.7 $\mathrm{min}),(R)-1-(4$ 'hydroxyphenyl)ethanol (15.1 $\mathrm{min})$.

3-Chloropropiophenone/3-chloro-1-phenylpropanol: $140^{\circ} \mathrm{C}, 30 \mathrm{~min}$, retention times: 3 -chloropropiophenone (16.0 $\mathrm{min}),(R)$-3-chloro-1-phenylpropanol (26.5 $\mathrm{min})$, (S)-3-chloro-1-phenylpropanol (26.9 min). Ethyl 4chloroacetoacetate/ethyl -4-chloro-3-hydroxybutyrate, ethyl acetylacetate/ethyl 3-hydroxybutyrate, methyl acetoacetate/methyl -3-hydroxybutyrate: $80^{\circ} \mathrm{C}(20 \mathrm{~min})$, $50^{\circ} \mathrm{C} / \mathrm{min}$ to $155^{\circ} \mathrm{C}(6 \mathrm{~min})$, retention times: ethyl 4chloroacetoacetate (24.2 $\mathrm{min})$, derivatized ethyl $(R)$-4chloro-3-hydroxybutyrate (19.1 $\mathrm{min})$, derivatized ethyl (S)-4-chloro-3-hydroxybutyrate (19.4 $\mathrm{min})$; ethyl acetylacetate (23.2 $\mathrm{min})$, derivatized ethyl $(R)$-3-hydroxybutyrate (17.3 $\mathrm{min})$, derivatized ethyl $(R)$-3-hydroxybutyrate (17.6 $\mathrm{min})$; methyl acetoacetate $(21.1 \mathrm{~min})$, derivatized methyl $(R)$-3-hydroxybutyrate $(15.2 \mathrm{~min})$, derivatized methyl $(R)$-3-hydroxybutyrate (15.4 min).

\section{Competing interests}

The authors declare that they have no competing interests.

\section{Authors' contributions}

P-XD and PW conducted the experiments. P-XD wrote the main text, figures and tables. $\mathrm{W}-\mathrm{YL}$ and $\mathrm{M}-\mathrm{HZ}$ corrected and helped to draft the manuscript. All authors have read and approved the final manuscript.

\section{Acknowledgements}

We wish to thank the National Science Found for Excellent Young Scholars (21222606), the State Key Program of National Natural Science Foundation of China (21336002), the NSFC (21376096), the Key Program of Guangdong Natural Science Foundation (S2013020013049), the National Key Basic Research Program of China (2013CB733500) and the Fundamental Research Funds for SCUT (2013ZG0003) for partially funding this work.

Received: 22 February 2014 Accepted: 5 June 2014

Published: 10 June 2014

\section{References}

1. Gamenara D, de Maria PD: Candida spp. redox machineries: an ample biocatalytic platform for practical applications and academic insights. Biotechnol Adv 2009, 27:278-285.
2. Kroutil W, Mang $H$, Edegger $K$, Faber $K$ : Recent advances in the biocatalytic reduction of ketones and oxidation of sec-alcohols. Curr Opin Cell Biol 2004, 8:120-126.

3. Bhattacharyya MS, Singh A, Banerjee UC: Asymmetric reduction of a ketone by wet and lyophilized cells of Geotrichum candidum in organic solvents. N Biotechnol 2012, 29:359-364.

4. Braun M, Sun B, Anselment B, Weuster-Botz D: Novel whole-cell biocatalysts with recombinant hydroxysteroid dehydrogenases for the asymmetric reduction of dehydrocholic acid. Appl Microbiol Biotechnol 2012, 95:1457-1468.

5. Silva VD, Stambuk BU, de Graca Nascimento M: Asymmetric reduction of (4R)-(-)-carvone catalyzed by Baker's yeast in aqueous mono- and biphasic systems. J Mol Catal B Enzym 2012, 77:98-104.

6. Rodrigues JAR, Moran PJS, Fardelone LC: Recent advances in the biocatalytic asymmetric reduction of acetophe-nones and $\alpha, \beta$-unsaturated carbonyl compounds. Food Technol Biotechnol 2004, 42:295-303.

7. Schmid A, Dordick JS, Hauer B, Kiener A, Wubbolts M, Witholt B: Industrial biocatalysis today and tomorrow. Nature 2001, 409:258-268.

8. Wohlgemuth R: Biocatalysis-key to sustainable industrial chemistry. Curr Opin Cell Biol 2010, 21:713-724.

9. Rocha LC, Ferreira HV, Luiz RF, Sette LD, Porto AL: Stereoselective bioreduction of 1-(4-methoxyphenyl) ethanone by whole cells of marine-derived Fungi. Mar Biotechnol 2012, 14:358-362.

10. Ni Y, Su YN, Li HD, Zhou JY, Sun ZH: Scalable biocatalytic synthesis of optically pure ethyl $(R)$-2-hydroxy-4-phenylbutyrate using a recombinant E.coli with high catalyst yield. J Biotechnol 2013, 168:493-498.

11. Prelog V: Specification of the stereospecificity of some oxido-reductases by diamond lattice sections. Pure App/ Chem 1964, 9:119-130.

12. Tujigami T, Sugai T, Ohta H: Microbial asymmetric reduction of ahydroxyketones in the anti-Prelog selectivity. Tetrahedron Asymmetry 2001, 12:2543-2549.

13. Groger H, Rollmann C, Chamouleau F, Sebastien I, May O, Wienand W, Drauz K: Enantioselective Reduction of 4-Fluoroacetophenone at high substrate concentration using a Tailor-made recombinant Whole-cell catalyst. Adv Synth Catal 2006, 349:709-712.

14. $\mathrm{Hu} J, \mathrm{Xu}$ Y: Anti-Prelog reduction of prochiral carbonyl compounds by Oenococcus oeni in a biphasic system. Biotechnol Lett 2006, 28:1115-1119.

15. Lavandera I, Holler B, Kern A, Ellmer U, Glieder A, de Wildeman S, Kroutil W: Asymmetric anti-Prelog reduction of ketones catalysed by Paracoccus pantotrophus and Comamonas sp. cells via hydrogen transfer. Tetrahedron Asymmetry 2008, 19:1954-1958.

16. Xiao ZJ, Zong MH, Lou WY: Highly enantioselective reduction of 4-(trimethylsilyl)-3-butyn-2-one to enantiopure (R)-4-(trimethylsilyl)-3butyn-2-ol using a novel strain Acetobacter sp. CCTCC M209061. Bioresour Technol 2009, 100:5560-5565.

17. Brautigam S, Dennewald D, Schurmann M, Lutje-Spelberg J, Pitner WR, Weuster-Botz D: Whole-cell biocatalysis: Evaluation of new hydrophobic ionic liquids for efficient asymmetric reduction of prochiral ketones. Enzyme Microb Technol 2009, 45:310-316.

18. Dennewald D, Pitner WR, Weuster-Botz D: Recycling of the ionic liquid phase in process integrated biphasic whole-cell biocatalysis. Process Biochem 2011, 46:1132-1137.

19. Zhang BB, Cheng J, Lou WY, Wang P, Zong MH: Efficient anti-Prelog enantioselective reduction of acetyltrimethylsilane to $(R)-1$ trimethylsilylethanol by immobilized Candida parapsilosis CCTCCM203011 cells in ionic liquid-based biphasic systems. Microb Cell Fact 2012, 11:108.

20. Wang XT, Yue DM, Zong MH, Lou WY: Use of ionic liquid to significantly improve asymmetric reduction of ethyl acetoacetate catalyzed by Acetobacter sp. CCTCC M209061 Cells. Ind Eng Chem Res 2013, 52:12550-12558.

21. Wu JJ, Gullo M, Chen FS, Giudici P: Diversity of Acetobacter pasteurianus strains isolated from solid-state fermentation of cereal vinegars. Curr Microbiol 2010, 60:280-286

22. Chen XH, Wei P, Wang XT, Zong MH, Lou WY: A novel carbonyl reductase with anti-Prelog stereospecificity from Acetobacter sp. CCTCC M209061: Purification and Characterization. PLoS One 2014, 9(4):e94543.

23. Chen XH, Wang XT, Lou WY, Li Y, Wu H, Zong MH, Smith TJ, Chen XD: Immobilization of Acetobacter sp. CCTCC M209061 for efficient asymmetric reduction of ketones and biocatalyst recycling. Microb Cell Fact 2012, 11:119. 
24. Xiao ZJ, Du PX, Lou WY, Wu H, Zong MH: Using water-miscible ionic liquids to improve the biocatalytic anti-Prelog asymmetric reduction of prochiral ketones with whole cells of Acetobacter sp. CCTCC M209061. Chem Eng Sci 2012, 84:695-705.

25. Gelo-Pujic M, Le Guyader F, Schlama T: Microbial and homogenous asymmetric catalysis in the reduction of 1-[3,5-bis(trifluoromethyl) phenyl]ethanone. Tetrahedron Asymmetry 2006, 17:2000-2005.

26. Kansal H, Banerjee U: Enhancing the biocatalytic potential of carbonyl reductase of Candida viswanathii using aqueous-organic solvent system. Bioresour Technol 2009, 100:1041-1047.

27. Quezada MA, Carballeira JD, Sinisterra JV: Monascus kaoliang CBS 302.78 immobilized in polyurethane foam using iso-propanol as co-substrate: optimized immobilization conditions of a fungus as biocatalyst for the reduction of ketones. Bioresour Technol 2009, 100:2018-2025.

28. Xie Y, Xu JH, Lu W, Lin G: Adzuki bean: a new resource of biocatalyst for asymmetric reduction of aromatic ketones with high stereoselectivity and substrate tolerance. Bioresour Technol 2009, 100:2463-2468.

29. Wang QY, Shen LH, Ye TT, Cao D, Chen R, Pei XL, Xie T, Li Y, Gong W, Yin XP: Overexpression and characterization of a novel (S)-specific extended short-chain dehydrogenase/reductase from Candida parapsilosis. Bioresour Technol 2012, 123:690-694.

30. Katz M, Sarvary I, Frejd T, Hahn-Hägerdal B, Gorwa-Grauslund M: An improved stereoselective reduction of a bicyclic diketone by Saccharomyces cerevisiae combining process optimization and strain engineering. Appl Microbiol Biotechnol 2002, 59:641-648.

31. Guo JL, Mu XQ, Xu Y: Integration of newly isolated biocatalyst and resinbased in situ product removal technique for the asymmetric synthesis of (R)-methylmandelate. Biotechnol Bioproc E 2010, 33:797-804

32. Stewart JD: Organic transformations catalyzed by engineered yeast cells and related systems. Curr Opin Biotechnol 2000, 11:363-368.

33. Wolfson A, Dlugy C: Baker's yeast catalyzed asymmetric reduction in glycerol. Tetrahedron Asymmetry 2006, 17:2043-2045.

34. Li YN, Shi XA, Zong MH, Meng C, Dong YQ, Guo YH: Asymmetric reduction of 2-octanone in water/organic solvent biphasic system with Baker's yeast FD-12. Enzyme Microb Tech 2007, 40:1305-1311.

35. Nakamura K, Matsuda T: Asymmetric reduction of ketones by the acetone powder of Geotrichum candidum. J Org Chem 1998, 63(24):8957-8964.

36. Wang XT, Chen XH, Xu Y, Lou WY, Wu H, Zong MH: Biocatalytic anti-Prelog stereoselective reduction of ethyl acetoacetate catalyzed by whole cells of Acetobacter sp. CCTCC M209061. J Biotechnol 2013, 163:292-300.

37. Yang GS, Xu JY, Ou ZM, Yao SJ: Asymmetric reduction of (S)-3-chloro-1phenyl propanol from 3-chloropropiophenone by preheated immobilized Candida utilis. Biotechnol Lett 2009, 31(12):1879-1883.

\section{Submit your next manuscript to BioMed Central and take full advantage of:}

- Convenient online submission

- Thorough peer review

- No space constraints or color figure charges

- Immediate publication on acceptance

- Inclusion in PubMed, CAS, Scopus and Google Scholar

- Research which is freely available for redistribution 